\title{
PENGGUNAAN TEKNOLOGI PEMBELAJARAN KULIAH DARING TERHADAP SIKAP MENTAL MAHASISWA DAN DOSEN DI ERA COVID-19
}

\author{
Lili Amaliah ${ }^{1}$ Arie Ardiyanti Rufaedah ${ }^{2}$ \\ Program Studi Kesehatan Masyarakat STIKes Mahardika Cirebon ${ }^{1,2}$ \\ lili.amaliah@gmail.com ${ }^{1}$ arieardiyantirufaedah@gmail.com²
}

\begin{abstract}
The corona virus was originally discovered when residents of the Chinese city of Wuhan contracted a disease caused by the SARS-CoV-2 virus, previously people assumed the symptoms experienced as the common cold, until WHO declared a COVID-19 pandemic. The Covid-19 corona virus also affects the world of education where the teaching and learning process which is usually carried out face-toface in the classroom due to the covid-19 pandemic, the teaching and learning process must be carried out by distance learning. This study aims to determine the relationship between online lectures and the mental attitude of students and lecturers. The sample in this study were students and lecturers of STIKes Mahardika Cirebon. The research method used is mixed methods research. The results of the study found a close relationship between online lectures and the mental attitude of the students participating in the lectures. This can be seen from the data processing and analysis showing that around $60.5 \%$ of students and lecturers are ready to adapt to online lectures, although there are some who find it difficult to use the application used as much as $32.5 \%$ but around $47.5 \%$ are ready to adapt. This can be overcome through rapid training in the use of supporting technology and the operationalization of the application. The online lectures conducted by the lecturers are accompanied by the assignment of many assignments in the conditions of the outbreak of the COVID-19 outbreak, and government policies that implement stay at home and work from home.
\end{abstract}

Keywords $\quad$ : Covid-19, Impact, Lecture, Online, Mental Attitude

\begin{abstract}
ABSTRAK
Virus corona pada awalnya ditemukan saat penduduk kota Wuhan Cina terjangkit penyakit disebabkan yang disebabkan oleh virus SARS-CoV-2, sebelumnya orang beranggapan gejala yang dialami sebagai flu biasa, sampai WHO mendeklarasikan pandemi COVID-19. Virus corona covid-19 turut serta mempengaruhi dunia pendidikan dimana proses belajar mengajar yang biasanya dilakukan secara tatap muka di ruang kelas akibat pandemi covid-19 proses belajar mengajar harus dilakukan dengan cara pembelajaran jarak jauh. Penelitian ini bertujuan untuk mengetahui hubungan perkuliahan online dengan sikap mental pada mahasiswa dan dosen. Sampel pada penelitian ini adalah mahasiswa dan dosen STIKes Mahardika Cirebon. Metode penelitian yang dilakukan menggunakan penelitian mixed methods. Hasil dari penelitian ditemukan hubungan yang erat antara perkuliahan online dengan sikap mental dari para mahasiswa peserta perkuliahan. Hal ini bisa dilihat dari data hasil pengolahan dan analisannya menunjukkan sekitar $60.5 \%$ mahasiswa dan dosen siap beradaptasi dengan perkuliahan online walaupun ada yang merasa kesulitan dalam penggunaan aplikasi yang dipakai sebanyak $32.5 \%$ namun sekitar $47.5 \%$ siap beradaptasi. Hal ini bisa diatasi melalui pelatihan yang cepat dalam penggunaan teknologi pendukung serta operasionalisasi aplikasi tersebut. Perkuliahan online yang dilakukan para dosen disertai dengan pemberian tugas yang banyak dalam kondisi merebaknya wabah COVID-19, dan kebijakan pemerintahan yang menerapkan stay at home serta working from home.
\end{abstract}

Kata Kunci : Covid-19, Dampak, Kuliah, Daring, Sikap Mental 


\section{PENDAHULUAN}

COVID-19 adalah penyakit infeksi baru yang diketahui dapat menyebabkan terjadinya gangguan pernapasan dan radang paru (Razi et al., 2020). Pertama kali ditemukan di Wuhan pada pertengahan Desember 2020, penyakit bersumber dari hewan yang etiologi menunjukkan Coronavirus baru. Semula dinamakan 2019 novel Coronavirus (2019-nCoV), tetapi kemudian WHO mengumumkan nama baru pada 11 Februari 2020 menjadi Coronavirus Disease (COVID-19) yang disebabkan oleh virus Severe Acute Respiratory Syndrome Coronavirus-2 (SARS-CoV-2) (WHO. report. 22, 2020, Zhou et al.2020). Virus ini dapat ditularkan dari manusia ke manusia dan telah menyebar secara luas di China dan lebih dari 200 negara dan teritori lainnya(WHO.report.70, 2020) COVID-19 pertama dilaporkan di Indonesia pada tanggal 2 Maret 2020. ada dua kasus terinfeksi COVID-19. Pada saat itu kasus global yang terkonfirmasi berjumlah 88.948 kasus dan 3.043 kasus kematian (WHO.report.42, 2020). Sementara di Indonesia ada sebanyak 1.790 kasus dengan positif COVID-19 dan 170 kasus kematian yang tersebar di 32 provinsi (Kemekes RI, update COVID-19, 2020). Dari data tersebut dapat dihitung Case Fatality Rate (CFR) sebesar 9\% untuk Indonesia sedangkan secara global sebesar $5 \%$.

Hasil studi epidemiologi dan virologi memberikan bukti bahwa COVID-19 menular dari orang bergejala kepada orang lain yang berada dalam kontak dekat melalui tetesan pernapasan, melalui kontak langsung dengan orang yang sudah terinfeksi, atau melalui kontak dengan benda dan permukaan yang terkontaminasi. (WHO,2020). Sejak itu, seolah sejarah manusia ditulis ulang. Berbagai rumah sakit menghadapi lonjakan pasien, sehingga menyebabkan jatuhnya layanan medis karena ketidaksiapan sarana dan fasilitas yang dimiliki. Penyakit ini punya karakter sangat cepat penyebarannya, dengan berinteraksi jarak dekat serta bersentuhan dengan penderita, maka sudah bisa mengantarkan seorang terjangkit penyakit ini. Sehingga para ahli kesehatan menyarankan untuk melakukan social distancing, physical distancing dan stay at home. Terus merebaknya penyakit ini ke berbagai tempat dan Negara, mengantarkan kita harus bisa beradaptasi dengan situasi ini. Hal ini meyebabkan banyak pemerintah di berbagai negara melakukan tidakan seperti karantina, isolasi sosial, perintah diam di rumah, penutupan perkantoran, penutupan lembaga pendidikan serta pengurangan jam kerja di perusahaan maupun pabrik dan lain-lain. Untuk melakukan pekerjaan rutin karena sangat dibutuhkan pemberlakuan penjadwalan pekerjaan dengan menggunakan protokol kesehatan yang ketat.

Sebagaimana Negara lain, Indonesia juga membuat kebijakan meliburkan seluruh lembaga pendidikan untuk beraktifitas di kelas bersama secara offline. Akan tetapi seluruh perguruan tinggi diminta menerapkan teknologi pembelajaran untuk perkuliahan via online. Hal ini bertujuan sebagai upaya mencegah penularan COVID- 19. Hal ini bukan menjadi sebuah masalah bagi beberapa perguruan tinggi yang memiliki sistem akademik berbasis daring. Namun akan menjadi masalah bagi perguruan tinggi yang belum memiliki akademik berbasis daring. Oleh karena itu perlu dilakukan study tentang dampak dari perubahan atau transformasi metode pembelajaran dari 
offline menjadi online terhadap mental civitas akademika.

Tujuan penelitian ini adalah untuk mengetahui penggunaan teknologi pembelajaran kuliah daring terhadap sikap mental mahasiswa dan dosen STIKes Mahardika Cirebon di era covid-19.

\section{METODE}

Metode penelitian yang dilakukan menggunakan penelitian mixed methods, yang pertama melakukan analisa statistik parametris dan non parametris dari data kuantitatif bedasarkan data statistik hasil pengolahan data yang diberikan, kemudian melakukan deskriptif kualitatif dengan menggambarkan dampak kuliah online kepada para mahasiswa dan dosen.

Langkah penelitian berikutnya yang dilakukan dengan teknik pengumpulan data melalui pengisian kuesioner yang di berikan kepada mahasiswa dan dosen. Sampel pada penelitian ini adalah mahasiswa dan dosen STIKes Mahardika Cirebon kemudian dilakukan analisis data, penyajian data, dan kesimpulan. Teknik pengumpulan data lewat survey, merupakan penelitian yang sumber data dan informasi utamanya diperoleh dari responden sebagai sampel penelitian dengan menggunakan kuesioner sebagai instrumen pengumpulan data, kuesioner berupa form dalam bentuk softfile (google form) dan link nya akan di kirim kepada para mahasiswa dan dosen melalui group, form kuesioner yang terkumpul di olah dengan menggunakan Software Excel untuk mendapatkan data berupa tampilan grafik, sehingga dari data penelitian ini dapat dieksplorasi untuk dibuatkan deskripsinya dampak kuliah online dihubungkan dengan sikap kejiwaan yang muncul dari para mahasiswa dan dosen. Kemudian di carikan penguatan melalui referensi yang didapat dari penelitian kejiwaan yang telah dilakukan dalam menghadapi kasus yang sama atau mirip untuk kemudian ditarik kesimpulan untuk dicarikan solusinya.

Berdasarkan bentuk pertanyaannya, kuesioner dapat dikategorikan dalam dua jenis, yakni kuesioner terbuka dan kuesioner tertutup. Kuesioner terbuka adalah kuesioner yang memberikan kebebasan kepada objek penelitian untuk menjawab. Sementara itu, kuesioner tertutup adalah kuesioner yang telah menyediakan pilihan jawaban untuk dipilih oleh objek penelitian. Seiring dengan perkembangan, beberapa penelitian saat ini juga menerapkan metode kuesioner yang memiliki bentuk semi terbuka. Penelitian ini dengan pertanyaan terbuka dengan menjawab pilihan jawaban yang sudah dibuat peneliti dengan cara menceklis jawaban: Sangat setuju (SS), Setuju (S), Ragu-ragu (RR), Tidak setuju (ST), Sangat Tidak Setuju (STS). Adapun Pertanyaan yang ada di kuesioner seperti terlihat pada tabel 1 .

\section{Tabel 1. Instrumen Penelitian}

\begin{tabular}{cl}
\hline No & \multicolumn{1}{c}{ Pertanyaan } \\
\hline 1 & $\begin{array}{l}\text { Saya sangat antusias melakukan kuliah } \\
\text { online }\end{array}$ \\
\hline 2 & $\begin{array}{l}\text { Saya kesulitan dengan penggunaan aplikasi } \\
\text { kuliah online }\end{array}$ \\
\hline 3 & $\begin{array}{l}\text { Tugas di kuliah online yang lebih banyak } \\
\text { daripada perkuliahan offline }\end{array}$ \\
\hline 4 & $\begin{array}{l}\text { Kalau memikirkan tugas kadang saya susah } \\
\text { tidur }\end{array}$ \\
\hline 5 & $\begin{array}{l}\text { Saya suka kuliah offline dikelas langsung } \\
\text { dari pada kuliah online }\end{array}$ \\
\hline
\end{tabular}

\section{HASIL}

Hasil dari pengolahan data menggunakan excel dari jawaban mahasiswa sesuai pertanyaan-pertanyaan yang dibuat, ditampilkan dalam bentuk 
grafik, yang bisa dilihat pada gambar 1 dan gambar 2 dibawah ini. Sebagai informasi untuk analisa dari hasil pengolahan data ada penggabungan kategori, kategori sangat setuju (SS) dan setuju (S) digabung menjadi satu, kategori ragu-ragu tersendiri dan kategori gabungan tidak setuju (TS) dan sangat tidak setuju (STS) menjadi satu juga.

\section{Antusias mengikuti kuliah online}

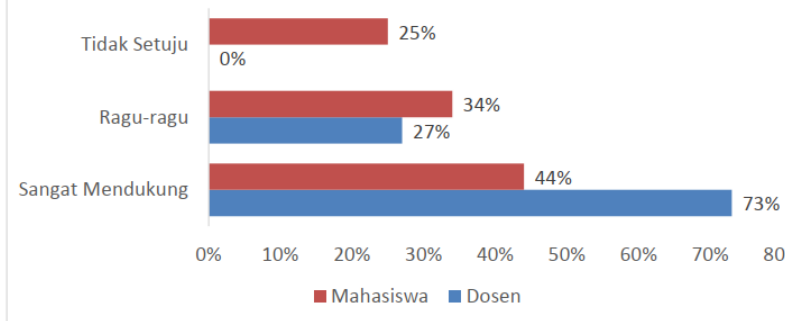

Analisa dari data diatas bahwa untuk dosen yang sangat mendukung sebanyak 73\% adanya kegiatan perkuliahan secara online karena terkait adanya pandemi serta adanya dukungan finansial sehingga bisa melakukan pembelajaran dan penyediaan peralatan yang dibutuhkan dalam perkulihan online dan $27 \%$ menyatakan ragu-ragu karena belum siap beradaptasi dan memiliki akses internet yang belum optimal. Sedangkan analisis hasil data untuk mahasiswa 0 yang sangat mendukung sebanyak $44 \%$ adanya kegiatan perkuliahan secara online karena telah siap secara finansial dan diantara mereka memiliki kemampuan yang baik secara akademik. Sebanyak 34\% menjawab raguragu karena belum bisa beradaptasi dengan perubahan sistem yang cepat.

\section{Saya Kesulitan dengan penggunaan aplikasi kelas online}

Analisa dari data tersebut secara umum bahwa dosen yang merasa tidak kesulitan dalam penggunaan aplikasi online sebanyak $50 \%$ dan mahasiswa sebanyak
$40 \%$. yang tidak kesulitan menggunakan aplikasi online dalam perkuliahan. Hal yang menjadi perhatian dari data diatas adalah masih adanya yang ragu-ragu dan mengalami kesulitan dalam penggunaan aplikasi online.

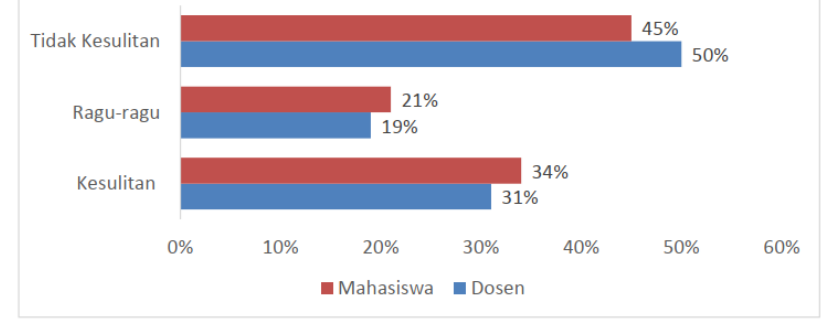

\section{Dosen memberikan tugas yang berlebihan daripada pembelajaran dikelas}

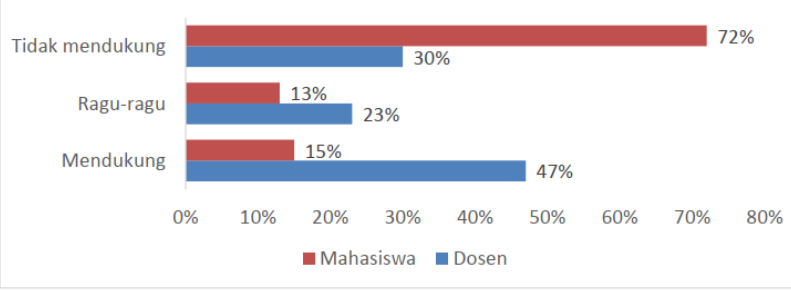

Analisis dari data diatas adalah untuk yang tidak mendukung adanya beban tugas jika dilihat dari sudut pandang mahasiswa sebesar $72 \%$ karena mata kuliah yang diampu oleh mereka ada sekitar 7 - 8 mata kuliah yang semuanya ada tugas dan jika dilihat dari sudut pandang dosen dan dosen sebesar $30 \%$ bahwa pemberian tugas yang berlebihan bukan merupakan solusi untuk melihat sejauh mana pemahaman mahasiswa terhadap mata kuliah yang diampu oleh dosen. Untuk yang menjawab ragu-ragu secara umum mengarah kepada tidak mau memberikan beban tugas yang berlebihan. Analisa lanjutan dari data yang menjawab tidak keberatan atas beban tugas. 
Kalau Memikirkan Tugas Kadang Saya Susah Tidur

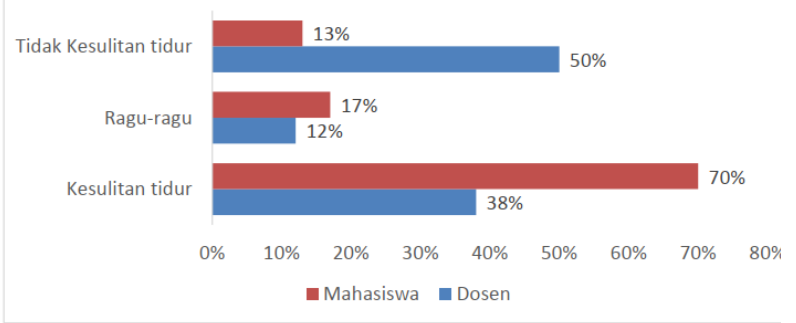

Melihat data diatas, baik dari jawaban dosen sebanyak 38\% menjawab kesulitan tidur, $12 \%$ menjawab ragu-ragu dan 50\% menjawab tidak kesulitan tidur. Adapun jawaban dari mahasiswa sebanyak $70 \%$ menjawab kesulitan tidur, $17 \%$ menjawab ragu-ragu dan sebanyak $13 \%$ menjawab tidak merasakan kesulitan tidur.

\section{Kesukaan kuliah offline dikelas langsung dari pada kuliah online}

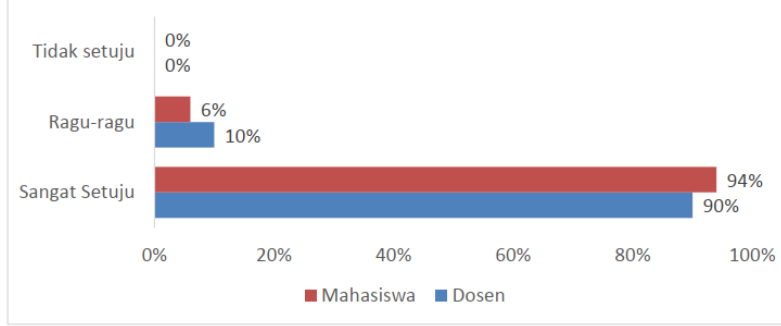

Hal yang menarik pada pertanyaan ke lima ini, jawaban dari dosen sebanyak, 90 $\%$ sangat setuju dengan perkuliahan tatap muka, sekitar $10 \%$ menjawab ragu-ragu, dan tidak ada orang tidak setuju dari pertanyaan ini. Adapun untuk mahasiswa lebih banyak lagi, sebanyak $94 \%$ merasa setuju perkuliahan tatap muka di kelas, tak satupun menjawab ragu-ragu, dan sebanyak $6 \%$ yang menjawab bahwa tidak setuju perkuliahan tatap muka.

\section{PEMBAHASAN}

Antusias Mengikuti Kuliah Online
Analisa dari data diatas bahwa untuk dosen yang sangat mendukung sebanyak $73 \%$ adanya kegiatan perkuliahan secara online karena terkait adanya pandemi serta adanya dukungan finansial sehingga bisa melakukan pembelajaran dan penyediaan peralatan yang dibutuhkan dalam perkulihan online dan $27 \%$ menyatakan ragu-ragu karena belum siap beradaptasi dan memiliki akses internet yang belum optimal. Sedangkan analisis hasil data untuk mahasiswa 0 yang sangat mendukung sebanyak $44 \%$ adanya kegiatan perkuliahan secara online karena telah siap secara finansial dan diantara mereka memiliki kemampuan yang baik secara akademik. Sebanyak 34\% menjawab raguragu karena belum bisa beradaptasi dengan perubahan sistem yang cepat karena pandemi COVID-19 ini sehingga belum siap beradaptasi atau karena hal lainnya semisal terjebak karena lockdown daerah melalui peraturan PSBB, sehingga harus tinggal dirumah yang akses internet belum optimal. Sebanyak 25\% menyatakan tidak setuju karena terbiasa dengan suasanan interaksi secara langsung yang bisa meningkatkan semangat kuliah. Akhir analisa dari pertanyaan ini. Menurut asumsi peneliti apapun yang terjadi baik mahasiswa maupun dosen atau tenaga administrasi sekalipun, harus siap dengan kondisi ini, baik karena sebab penyebaran penyakit atau alasan lainnya yang menyebabkan seperti ini. Hasil penelitian ini sejalan dengan hasil penelitian yang dilakukan oleh (Kusnayat,2020) yang mengatakan lebih banyak mahasiswa yang setuju untuk melakukan pembelajaran daring. Hasil Penelitian ini juga sejalan dengan penelitian yang dilakukan oleh (Karmila,2020) yang melakukan penelitian pada dua universitas yang berbeda, 
dilakukan penelitian pada mahasiswa sebanyak $48 \%$ mahasiswa tidak antusias dalam pelaksanaan pembelajaran online.

\section{Kesulitan dengan penggunaan aplikasi kelas online}

Analisa dari data tersebut secara umum bahwa tidak lebih dari 50\% yang tidak kesulitan menggunakan aplikasi online dalam perkuliahan. Hal yang menjadi perhatian dari data diatas adalah masih adanya yang ragu-ragu dan mengalami kesulitan dalam penggunaan aplikasi online karena perkuliahan online kemungkinan masih menjadi alternatif saat ini ketika wabah COVID-19 masih merajalela, dan bahkan hampir semua perguruan tinggi melakukan perkuliahan online sampai pemerintahan dalam hal ini, MENDIKBUD memutuskan kuliahan tatap muka lagi, walaupun perkuliahan online ini bagi perguruan tinggi tertentu akan menjadi alternatif perkuliahan kedepan institusinya. Analisa lanjutan dari data ini, sebagai peringatan kepada institusi perguruan tinggi segera melakukan terobosan alih teknologi melalui berbagai pelatihan penguasaan penggunaan aplikasi ini. Jikalau terlambat maka akan menjadi beban kelancaran perkuliahan yang berakibat keberbagai kebijakan serta berimbas kepada nilai akreditasi perguruan tinggi tersebut, sebagai catatan penelitian dilakukan kepada mahasiswa tingkat 1 semester 1 artinya mahasiswa katagori mahasiswa baru atau masih proses peralihan. Menurut asumsi peneliti hal yang perlu perhatian dari peristiwa ini dampak kepada mental mahasiswa, manakala masalah ini tidak segera dicarikan solusinya, sebagaimana analisa dipertanyaan pertama, ini akan menjadi jalan kegagalan studi mahasiswa. Hasil penelitian ini sejalan dengan hasil penelitian yang dilakukan oleh (Kusnayat,2020) yang mengatakan tidak lebih dari 50\% mahasiswa yang merasa kesulitan untuk menggunakan aplikasi yang digunakan untuk pembelajaran daring. Hasil Penelitian ini juga sejalan dengan penelitian yang dilakukan oleh (Karmila,2020) yang melakukan penelitian pada dua universitas yang berbeda, dilakukan penelitian pada mahasiswa sebanyak $30 \%$ mahasiswa merasa kesulitan dalam penggunaan aplikasi pembelajaran online, hal ini dikarenakan didaerah rumah mereka sulit untuk menemukan jaringan yang bagus untuk koneksi internet yang stabil.

\section{Dosen memberikan tugas yang berlebihan daripada pembelajaran dikelas}

Analisis dari data diatas adalah untuk yang tidak mendukung adanya beban tugas jika dilihat dari sudut pandang mahasiswa karena mata kuliah yang diampu oleh mereka ada sekitar $7-8$ mata kuliah yang semuanya ada tugas dan jika dilihat dari sudut pandang dosen bahwa pemberian tugas yang berlebihan bukan merupakan solusi untuk melihat sejauh mana pemahan mahasiswa terhadap mata kuliah yang diamu oleh dosen. Untuk yang menjawab ragu-ragu secara umum mengarah kepada tidak mau memberikan beban tugas yang berlebihan. Analisa lanjutan dari data yang menjawab tidak keberatan atas beban tugas menurut asumsi peneliti pihak perguruan tinggi bisa melakukan pendekatan akademis kepada mereka melalui para dosen atau aturan lewat prodi masingmasing untuk mengoptimalkan peran mereka membantu para mahasiswa lain dengan berbagai kegiatan yang di fasilitasi kampus atau dengan kreatifitas mereka 
sendiri yang terpantau, karena kalau tidak tertangani akan menjadi beban kejiwaan bagi para mahasiswa seperti ini mengalami kelainan kejiwaan disebabkan karena stres berkelanjutan. Hasil penelitian ini sejalan dengan hasil penelitian yang dilakukan oleh (Kusnayat, 2020) yang mengatakan bahwa lebih dari 50\% mahasiswa setuju dengan pertanyaan ini. Hasil Penelitian ini juga sejalan dengan penelitian yang dilakukan oleh (Karmila,2020) yang melakukan penelitian pada dua universitas yang berbeda, dilakukan penelitian pada mahasiswa sebanyak $60 \%$ mahasiswa setuju bahwa banyak dosen yang lebih banyak memberikan tugas dari pada pembelajaran didalam kelas.

\section{Kalau memikirkan tugas kadang saya susah tidur}

Melihat data diatas, baik dari jawaban dosen sebanyak 38\% menjawab kesulitan tidur, $12 \%$ menjawab ragu-ragu dan $50 \%$ menjawab tidak kesulitan tidur. Adapun jawaban dari mahasiswa sebanyak $70 \%$ menjawab kesulitan tidur, $17 \%$ menjawab ragu-ragu dan sebanyak $13 \%$ menjawab tidak merasakan kesulitan tidur. Ini merupakan benang merah bahwa beban tugas yang berlebihan, besar kemungkinan akan berakibat stress, walaupun pada tingkat stress rendah, sedang dan berat tergantung bagaimana para dosen dan mahasiswa memaintance dirinya dari permasalahan ini sehingga menemukan formula penyelesaiannya. Hasil penelitian ini sejalan dengan hasil penelitian yang dilakukan oleh (Kusnayat,2020) yang mengatakan sebanyak $70 \%$ mahasiswa mengaku menjadi susah tidur karena memikirkan tugas. Hasil Penelitian ini juga sejalan dengan penelitian yang dilakukan oleh (Karmila,2020) yang melakukan penelitian pada dua universitas yang berbeda, dilakukan penelitian pada mahasiswa sebanyak $45 \%$ mahasiswa merasa kesulitan untuk tidur karena memikirkan tugas yang terlalu banyak dan selalu begadang dalam menyelesaikan tugasnya.

\section{Saya suka kuliah offline dikelas langsung dari pada kuliah online}

Hal yang menarik pada pertanyaan ke lima ini, jawaban dari dosen sebanyak, 90 $\%$ sangat setuju dengan perkuliahan tatap muka, sekitar $10 \%$ menjawab ragu-ragu, dan tidak ada orang tidak setuju dari pertanyaan ini. Adapun untuk mahasiswa lebih banyak lagi, sebanyak $94 \%$ merasa setuju perkuliahan tatap muka di kelas, tak satupun menjawab ragu-ragu, dan sebanyak $6 \%$ yang menjawab bahwa tidak setuju perkuliahan tatap muka. Analisa dari data tersebut hampir mayoritas para mahasiwa rindu dengan perkuliahan tatap muka dikelas, walaupun sebagian dari mereka siap dengan perkuliahan online. Data ini akan lebih menarik ketika para peneliti melakukan analisa dengan tinjauan berbagai disiplin ilmu, ini akan menemukan temuan- temuan baru yang sangat menyentuh dan bermanfaat. Akan tetapi untuk penelitian ini, peneliti mencoba mengurai tentang fenomena ini, kenapa dikatakan fenomena karena beberapa kampus yang disurvei walaupun hasilnya tidak ditampilkan disini, jawabannya diatas $90 \%$ mereka ingin kuliah tatap muka, sebenarnya kalau dilihat dengan kacamata sistem pendidikan yang melibatkan dosen, ada nilai yang tidak bisa di rasakan, dibayangkan dengan kata-kata dan tampilan fisik akan tetapi ini mendalam, diantarnya disini ada pengormatan, kecintaan, persaudaraan, kasih sayang serta kerinduan 
bertemu langsung yang terjadi antara mahasiswa dengan dosennya begitupun sebaliknya. Hasil penelitian ini sejalan dengan hasil penelitian yang dilakukan oleh (Kusnayat,2020) yang mengatakan sebanyak 90\% mahasiswa setuju untuk melakukan perkuliahan secara offline. Hasil Penelitian ini juga sejalan dengan penelitian yang dilakukan oleh (Karmila,2020) yang melakukan penelitian pada dua universitas yang berbeda, dilakukan penelitian pada mahasiswa sebanyak 92\% mahasiswa setuju untuk melakukan pembelajaran offline karena mereka merasa pembelajaran offline lebih efektif dan mereka lebih memahami materi yang disampaikan tanpa terganggu oleh jaringan.

\section{KESIMPULAN}

Hasil dari penelitian ditemukan hubungan yang erat antara perkuliahan online dengan sikap mental dari para mahasiswa peserta perkuliahan. Hal ini bisa dilihat dari data hasil pengolahan dan analisannya menunjukkan dari data yang didapatkan dari penelitian yang dilakukan kepada mahasiswa dan dosen, sekitar 60.5 $\%$ mahasiswa dari perguruan tinggi yang menjadi objek penelitian siap berdaptasi dengan perkuliahan online walaupun ada yang merasa kesulitan dalam penggunaan aplikasi yang dipakai sebanyak diangka $32.5 \%$ tapi sekitar $47.5 \%$ siap beradaptasi. Hal ini bisa diatasi melalui pelatihan yang cepat dalam penggunaan teknologi pendukung serta operasionalisasi aplikasi tersebut. Perkuliahan online yang dilakukan para dosen disertai dengan pemberian tugas yang banyak dalam kondisi merebaknya wabah COVID-19, dan kebijakan pemerintahan anjuran stay at home serta working from home. Hal yang menarik dari penelitian ini menunjukkan hampir seluruh dosen dan mahasiswa memilih dan lebih suka perkuliahan tatap muka di kelas di banding perkuliahan online.

\section{UCAPAN TERIMAKASIH}

Ucapan terimakasih bagi seluruh Mahasiswa dan dosen STIKes Mahardika Cirebon. Yang sudah membantu dan mendukung seluruh proses penelitian ini. Dan sudah ingin membantu untuk menjadi sampel pada penelitian ini.

\section{DAFTAR PUSTAKA}

Abbas, H. (2014). Pengertian Mental. [Online] Tersedia: http://hakamabbas. blogspot.com/2014/01/pengertianmental.html

Abdel-Fattah HMM." Emotional Intelligence and Emotional Stability in Crises". Journal of Psychiatry and Psychiatric Disorders. April 2020, Volume 4, Issue 2. Doi:10.26502/jppd.2572-519X0090.

Agus Kusnayat, Agus Sofwan."Komputer dan Internet: Media Percepatan Penguasaan Materi Perkuliahan". Vocational Education In IT Polytechnic To Meet The Industrial Requirement With Campus. Bandung, 17 Desember 2009. Hal.1-5.

Arief S. Sadiman, R. Rahardjo, Anung Haryono, Rahardjito. 1996. Media Pendidikan : Pengertian, Pemanfaatan, dan Pengembangannya. Jakarta : CV. Rajawali.

Aristo Rahadi. 2003. Media Pembelajaran. Jakarta : Depdiknas.

Azhar Arsyad. 1997. Media Pembelajaran. Jakarta : PT. Raja Grafindo Persada.

Boidurjo Rick Mukhopadhyay,Bibhas K Mukhopadhyay." COVID-19 and 
'Zoom' for Remote Teaching: Enhancing Student Engagement". May 2020.

https://www.researchgate.net/publicati on/341151549

Chakraborty, M. and Muyia Nafukho, F. (2014), "Strengthening student engagement: what do students want in online courses?", European Journal of Training and Development, Vol. 38 No. 9, pp. 782-802. https://doi.org/10.1108/EJTD-11-20130123.

Chen, S., Zhang, Z., Yang, J., Wang, J., Zhai, X., \& Bärnighausen, T., et al. (2020). Fangcang shelter hospitals: a novel concept for responding to public health emergencies. The Lancet. https://doi.org/10.1016/S01406736(20)30744-3.

Conrad Hughes." Some implications of COVID-19 for remote learning and the future of schooling". April, 2020, No.36 - IBE-UNESCO. Darmalaksana, W., Hambali, R. Y. A., Masrur, A., \& Ushuluddin, F. (2020). Analisis Pembelajaran Online Masa WFH Pandemic Covid-19 sebagai Tantangan Pemimpin Digital Abad 21. pp.1-12.

Denissa Alfiani, dkk. 2016. Pembelajaran Berbasis Video Untuk Anak Generasi Z.Prosiding Inovasi Pendidikan di Era Big Data dan Aspek Psikologinya .ISSN: 2548- 5407. PascaSarjana Universitas Negeri Malang. hal 85-92.

Dhia Fauzia Rahman, Kirana Mukharomah, Nurul Qomariah,Wardah Hafidz Maesafaroh, Dian Eky Pratiwi." Penggunaan Analitik Hirarki Proses Dalam Menentukan Preferensi Platform Pembelajaran Daring Selama Masa Tanggap Darurat COVID-19 Pada Mahasiswa UGM Yogyakarta".April 2020 DOI: 10.13140/RG.2.2.11562.98248

Elliot, Stephen N., et al. 2000. Educational Psychology : Effective teaching,
Effective $\quad \mathrm{rd}$

learning. 3

.Boston:McGraw-Hill.

Giorgi Basilaia, David Kvavadze.” Transition to Online Education in Schools during a SARS-CoV-2 Coronavirus (COVID-19) Pandemic in Georgia". Pedagogical Research, April 2020. https://doi.org/10.29333/pr/7937.

Ismail Akbar Brahma.” Penggunaan Zoom Sebagai Pembelajaran Berbasis Online Dalam Mata Kuliah Sosiologi dan Antropologi Pada Mahasiswa PPKN di STKIP Kusumanegara Jakarta”. Jurnal Ilmu Pendidikan Nonformal. Mei 2020. Volume 06 No. 02. http://ejurnal.pps.ung.ac.id/index.php/ AKSARA/index.

Jaka Wijaya Kusuma, Hamidah.” Perbandingan Hasil Belajar Matematika Dengan Penggunaan Platform Whatsapp Group Dan Webinar Zoom Dalam Pembelajaran OnlinePada Masa Pandemik COVID 19". Jurnal Ilmiah Pendidikan Matematika,2020. Volume 5 Nomor 1 P-ISSN: 2502-7638; E-ISSN: 2502839.

Karmila, Sarah, (2020). Pengaruh pembelajaran daring dan kesehatan mahasiswa di di universitas $\mathrm{X}$ dan $\mathrm{Y}$. Edu-tech. Jurnal Edukasi dan Teknologi Pembelajaran. Volume 1, No. 2 Edisi Juni 2020

Kusnayat,Agus .(2020). Pengaruh Teknologi Pembelajaran Online terhadap mental mahasiswa. Edu-tech. Jurnal Edukasi dan Teknologi Pembelajaran. Volume 1, No. 2 Edisi Juni 2020

La Ode Anhusadar." Persepsi Mahasiswa PIAUD terhadap Kuliah Online di Masa Pandemi Covid 19". Journal of Islamic Early Childhood Education. April 2020.

Leslie, H. (2019), "Trifecta of Student Engagement: A framework for an online teaching professional 
development course for faculty in higher education", Journal of Research in Innovative Teaching \& Learning, Vol. aheadof-print No. ahead-of-print. https://doi.org/10.1108/JRIT-10-20180024.

Michael Molinda, 2005, Instrucsional Technology and Media for Learning New Jersey Colombus, Ohio Ms. Veena Shenoy, Ms. Sheetal Mahendra, Ms. Navita Vijay." COVID 19 Lockdown: Technology Adaption, Teaching, Learning, Students Engagement and Faculty Experience". Mukt Shabd Journal. April 2020. Volume IX, Issue IV, APRIL/2020 ISSN NO : 2347-3150.

Nur Rohim Yunus, Annissa Rezki, "Kebijakan Pemberlakuan Lockdown Sebagai Antisipasi Penyebaran Corona Virus Covid-19”. Jurnal Sosial \& Budaya Syar-i FSH UIN Syarif Hidayatullah Jakarta, 2020. Vol. 7 No. 3, pp.227-238, DOI: 10.15408/sjsbs.v7i3.15083-227.

Oemar Hamalik. 1982. Media Pendidikan. Bandung : Alumni. Thomas L. Friedman." The World Is Flat 3.0: A Brief History of the Twenty-first Century. I, New York, 2005: pp. 491501.

WHO (2020) Audio emergencies COVID19 Press Converence https://www.who.int/docs/defaultsource/coronaviruse/transcripts/whoaudioemergencies-coronavirus-pressconference-full20mar2020.pdf?sfvrsn=1eafbff_0

WHO. 2020. Rolling Updates on Coronavirus Disease (COVID-19). [Online] Tersedia pada: www.who.int [Diakses 8 april 2020].

WHO-a. 2020. WHO Director-General"s opening remarks at the media briefing on Internet. https://www.who.int/dg/speeches/detail /who-director-generals-opening remarks-at-the-media-briefing-onCOVID-19---11-march-2020.[Diakses 7 april]

WHO. report.22. (2020). Novel Coronavirus ( 2019-nCoV ).Situation Report-22. February.

WHO. report.42. (2020). Coronavirus disease 2019.Situation Report 42. World Health Organization, 2019(March), 2633. https://doi.org/10.1001/jama.2020.263 3

WHO. report.52. (2020). Coronavirus disease 2019. Situation-52. World Health Organization, 2019(March), 2633.

https://doi.org/10.1001/jama.2020.263 3

WHO. report.70. (2020). Coronavirus disease 2019, Situation Report - 70.

World Health Organization, 2019(March), 2633. https://doi.org/10.1001/jama.2020.263 3

WHO. report.73. (2020). Coronavirus disease 2019.Situation Report-73. World Health

Winkel, W.S. 1996. Psikologi Pengajaran. Jakarta : Gramedia Widiasarana Indonesia. Organization, 2019(April), 2633. https://doi.org/10.1001/j 